\title{
Effect of long-term dietary lead exposure on some maturation and reproductive parameters of a female Prussian carp (Carassius gibelio B.)
}

\author{
Ewa Luszczek-Trojnar • Ewa Drąg-Kozak • Paweł Szczerbik • \\ Magdalena Socha $\cdot$ Włodzimierz Popek
}

Received: 28 June 2013 / Accepted: 18 September 2013 /Published online: 29 September 2013

(C) The Author(s) 2013. This article is published with open access at Springerlink.com

\begin{abstract}
Lead is reported to be an endocrine disruptor. In the current study, we exposed female Prussian carp to artificial feed, supplemented with five doses of dietary $\mathrm{Pb}(0,1$ (control), 8, 13, 24, and $49 \mathrm{mg} / \mathrm{kg}$ ) over either a 24-month period or a 12-month period, followed by further 12 months where the fish were fed the control diet. Periodically, oocyte maturation, gonadosomatic index (GSI), ability to secret luteinizing hormone ( $\mathrm{LH})$ as well as gonad $\mathrm{Pb}$ concentrations were measured. It was found that the reproductive system of the female Prussian carp is not indifferent to chronic exposure to lead. The negative effect was manifested by a decrease in the GSI after 12 months despite the fact that a higher proportion of oocytes at more advanced maturity stages were concurrently observed. After 12 months of exposure, the effect on LH secretion varied according to the dose. In the group exposed to the lowest dose $(8 \mathrm{mg} / \mathrm{kg})$, LH decreased spontaneously, and in the groups exposed to the highest two doses ( 24 and 48 $\mathrm{mg} / \mathrm{kg}$ ), a significantly higher LHRH-A-stimulated LH secretion was observed. After 24 months of lead exposure, the effects on oocyte maturation and size and on GSI values were not pronounced. Analysis of the effect of lead exposure on LH secretion showed that the relationships were similar to those observed after 12 months but nonsignificant. During chronic a 24-month period exposure to $\mathrm{Pb}$, Prussian carp female appears to acclimate to $\mathrm{Pb}$ doses used in the experiment. After 12 months of exposure and 12 months of depuration, the levels of spontaneous and stimulated LH secretion observed in all the
\end{abstract}

Responsible editor: Thomas Braunbeck

E. Łuszczek-Trojnar $(\bowtie) \cdot$ E. Drag-Kozak $\cdot$ P. Szczerbik •

M. Socha $\cdot$ W. Popek

Department of Ichthyobiology and Fisheries,

University of Agriculture in Kraków, Spiczakowa 6,

30-199 Kraków-Mydlniki, Poland

e-mail: e.trojnar@ur.krakow.pl groups were similar to the control, which is evidence that depuration eliminates the previously observed effects of exposure to lead. Lead is easily accumulated in the ovary, reaching a fivefold higher level $(0.8 \mathrm{mg} / \mathrm{kg}$ tissue $)$ compared to the control $(0.15 \mathrm{mg} / \mathrm{kg}$ tissue), but after discontinuation of exposure, this organ is quickly depurated. The results indicate that environmental $\mathrm{Pb}$ can be a potent endocrine disruptor affecting ovarian steroidogenesis, gametogenesis, and ovulation, which may lead to adverse impacts on fish reproduction and population density and that female Prussian carp become resistant to the negative effects of lead with advancing age, and their organs cope by reaching a state of homeostasis.

Keywords Lead · Prussian carp · Oocyte maturation . Luteinizing hormone secretion · Bioaccumulation · Depuration

\section{Introduction}

Lead is a nonessential metal; however, it is easily absorbed into the body through ingestion or inhalation and undergoes bioaccumulation. Due to its environmental ubiquity, especially as a result of anthropogenic contaminants, the risk of exposure to the effects of lead is very high (Has-Schön et al. 2008; Ebrahimi and Taherianfard 2011; Yi and Zhang 2012; Mahalakshmi et al. 2012). The negative impact of lead on reproductive function was demonstrated in many studies with mammals (Al-Saleh et al. 2008; Iavicoli et al. 2004, 2006; Ronis et al. 1996; Taupeau et al. 2003; Vyskocil et al. 1990). Lead can easily penetrate cell membranes and cross the blood-brain barrier. It is a known endocrine-disrupting chemical in mammals and is believed to produce this effect through the hypothalamic-pituitary axis (Lucchi et al. 1981). Iavicoli et al. (2006) observed that in successive generations of mice 
exposed to different doses of lead, the onset of sexual maturity depended on blood lead concentration, being delayed by $20-$ $30 \%$ with elevated concentration and shorter with decreasing concentration.

Surface waters and their inhabitants are particularly vulnerable to contaminants from effluents, soil contaminants from surface runoff, and contaminants from atmospheric precipitation. During a long-term exposure to low doses of metals, fish may show no noticeable reaction in terms of growth or survival parameters, but chronic contamination may adversely affect their reproductive organs, leading to reduced reproductive parameters and disappearance of the population (Kime 1995). There exist some data confirming that the chronic exposure to steroid hormone mimics may impair reproductive function and critically assesses the weight of evidence for endocrine disruption in wildlife (Sumpter and Jobling 2013). Kidd et al. (2007) observed that a chronic exposure of fathead minnow (Pimephales promelas) to low concentrations of the potent $17 \alpha$-ethynylestradiol led to feminization of males and ultimately caused a near extinction of this species from the lake. In this context, studies are performed to determine the negative impact of nonessential metals, including cadmium, mercury, or lead, on the reproductive function in fish. Chronic exposure to cadmium influences reproductive disruption in fish, inhibiting induction of vitellogenin (Olsson et al. 1995), delaying oogenesis in brown trout (Brown et al. 1994) enhancing luteinizing hormone (LH) secretion, and decreasing parameters of gonadosomatic index (GSI) and ovulation in Prussian carp (Szczerbik et al. 2006). Also, deleterious effects of mercury on gonad's growth, fish spawning, and egg production and development, fertilization, and hatching were observed (Birge et al. 1979; Snarski and Olson 1982; Ram and Sathyanesan 1983; Ram and Joy 1988; Kirubagaran and Joy 1992; Crump and Trudeau 2009). The toxic effect of lead on gametes was shown in studies with both male and female animals (Goyer 1986). Ruby et al. (1993) reported decreased transformation of spermatogonia to spermatocytes in sexually maturing rainbow trout following exposure to low levels of waterborne lead. Weber (1993) observed that multiple effects on reproductive behavior and overall reproductive success in adult fathead minnows, where lead suppressed spermatocyte production and retarded ovarian development, decreased the number of eggs oviposited, increased interspawn periods, and suppressed embryo development. Thomas (1988) reported the decreases in estradiol levels in female Atlantic croaker following exposure to dietary lead. Khan (2000) demonstrated that lead and Aroclor 1254 significantly decreased LH levels in Atlantic croaker in response to stimulation by an LHRH analog in vivo and reduced gonadal growth when administered at a dose of $15 \mathrm{mg} / \mathrm{kg}$ body weight for 30 days.

Considering that lead can penetrate into the brain and influence the maturation and reproductive processes, this study was undertaken to determine if long-term exposure of juvenile fish to dietary lead for 12 months will affect gonadal maturation, vitellogenesis, and spontaneous LH secretion, as well as reproductive processes, when studying the response of females to the hormonal stimulation of ovulation.

An additional objective was to investigate the effect of further exposure to lead at different doses on gonadal recovery before the next spawning period and LH secretion after 24 months of exposure.

In order to examine whether the consequences of 12-month lead exposure are reversible, in some of the fish, the exposure was terminated and for the next 12 months, they were subjected to depuration and received control feed.

A further objective of this study was to examine the process of lead bioaccumulation in the ovaries during 24 months of exposure as well as changes in lead concentration during the 12-month depuration period.

The Prussian carp was chosen as an experimental model due to its low sensitivity and high resistance to adverse environmental conditions. The Prussian carp is an important subject for model experiments involving heavy metals, biomonitoring, and industrial and amateur fishing (Syasina et al. 2012). This species is widely distributed in Europe, Siberia, and Asia, and in the eastern regions, it is represented by bisexual populations, with single monosex polyploid populations (Fan and Liu 1990). Most European populations are monosex populations, living as triploid females that reproduce gynogenetically (Boroń et al. 2011), and such a population was chosen for this study. Diploid and triploid individuals of Prussian carp spawn in batches, and they have an asynchronous ovary, which contains oocytes in all developmental stages (Boroń et al. 2011).

The dietary lead levels to which Prussian carp was exposed in the present experiment were based on the reported concentrations of this metal in benthic organisms that are the Prussian carp's natural food, which may range from 0 to as much as $792 \mu \mathrm{g} \mathrm{Pb} \mathrm{g}^{-1}$ dry weight (dw) (Hodson et al. 1978; Woodward et al. 1994). Given that the study was aimed to show the effect of long-term exposure (the normal level of lead in invertebrates in an unpolluted environment should not exceed $1 \mu \mathrm{g} \mathrm{g}^{-1}$ (Farag et al. 1999), we chose concentrations simulating the average degree of environmental contamination $\left(8,13,24\right.$, and $\left.49 \mathrm{mg} \mathrm{kg}^{-1}\right)$ to find out if their constant presence in fish diets will significantly affect some reproductive parameters as well as the bioaccumulation and subsequent elimination of lead from Prussian carp gonads.

\section{Materials and methods}

Fish

Four hundred forty female Prussian carps Carassius gibelio B. originating from "Górki" Fish Farm in Wiślica, Poland, 
were used in the study. Fish were stocked in 14 300-1 aquaria (30 fish per aquarium) in water supplied from the Municipal Waterworks in Cracow (average temperature of $17^{\circ} \mathrm{C}, \mathrm{pH} \mathrm{7.7}$, dissolved oxygen of $10.5 \mathrm{mg}^{-1}$, water hardness of $127 \mathrm{mg}$ $\mathrm{CaCO}_{3} \mathrm{l}^{-1}$ ). In addition, the water was aerated and filtered. The experiment was preceded by a 4-month adaptation period when fish were fed a control diet (lead concentration of $0.1 \mathrm{mg} \mathrm{kg}^{-1} \mathrm{dw}$ ). Exposure to lead began when fish were 9 months old, had an average body weight (b. wt) of $20 \mathrm{~g}$, and body length of $10 \mathrm{~cm}$. Fish were divided into five groups which were fed control pellets (control group) and pellets contaminated with different concentrations of lead $(8,13$, 24, and $49 \mathrm{mg} \mathrm{Pb} \mathrm{kg}^{-1}$ ) for two exposure periods of 12 and 24 months. Pellets of complete feed for Prussian carp were produced by the Institute of Ichthyobiology and Aquaculture of the Polish Academy of Sciences in Gołysz, using grains, oilseed, fish meal, vitamin, and mineral supplements as components. The feed was specified to contain $37 \%$ crude protein, $12 \%$ crude fat, and $31 \%$ carbohydrates. Control and experimental pellets were prepared in the same way, but no $\mathrm{Pb}$ was added to the control feed. Lead acetate trihydrate $(\mathrm{Pb}$ $\left.\mathrm{CH}_{3} \mathrm{COO}\right)_{2} \cdot 3 \mathrm{H}_{2} \mathrm{O}$; POCh S.A.) was added in proper proportions to standard ingredients before the pelletizing process during pellet production. Analysis of lead concentrations in pellet samples showed the following mean levels: control group -0.113 $( \pm 0.03) \mathrm{mg} \mathrm{kg}^{-1}$, group 2-8.07 $( \pm 0.11) \mathrm{mg} \mathrm{kg}^{-1}$, group 3$13.11( \pm 0.14) \mathrm{mg} \mathrm{kg}^{-1}$, group $4-23.71( \pm 0.18) \mathrm{mg} \mathrm{kg}^{-1}$, and group 5-48.62 $( \pm 0.24) \mathrm{mg} \mathrm{kg}^{-1} \mathrm{dw}$.

After 12 months of exposure, each experimental group was divided into two groups of fish, one of them were under the same treatment and the second (groups: 2-dep, 3-dep, 4-dep, and 5-dep) experienced a depuration period of 12 months and received the control feed until the end of the experiment. Throughout the study, fish were fed once daily a ration that amounted to $3 \%$ of their body weight. Feed intake was recorded.

The mean body weight after the 12 months of exposure ranged from $27.1 \pm 4 \mathrm{~g}$ of fish in group 3 exposed to $13 \mathrm{mg}$ $\mathrm{Pb} \mathrm{kg}{ }^{-1}$ for 12 months to $40.4 \mathrm{~g}$ in the control group. After 24 months of the experiment, mean body weight ranged from $34 \pm 7 \mathrm{~g}$ of fish in group 5-dep to $74 \pm 20 \mathrm{~g}$ in group 2 , where female fish were exposed to $8 \mathrm{mg} \mathrm{Pb} \mathrm{kg}^{-1}$ (Table 1).

\section{Tissue sampling}

At 3, 6, 12, 15, 18, and 24 months of the experiment, gonad samples were collected from 8 to 10 randomly harvested fish from each group. At 6, 12, and 24 months, the gonads were removed, weighed, and approximately $1-\mathrm{cm}^{2}$ mid-ovarian samples were placed in Bouin's fixative (Humason 1967) for $24 \mathrm{~h}$ for later histological analysis. The rest of the ovary was frozen until analysis of lead concentration. At 3, 15, and
18 months, ovary samples were taken only for $\mathrm{Pb}$ concentration analysis.

Histological analysis

Histological slides were prepared from paraffin blocks. Paraffin blocks were sectioned on a microtome at $8 \mu \mathrm{m}$, mounted on slides, and stained with hematoxylin and eosin (Zawistowski 1986). The preparations were analyzed by observing the stage of gonad and oocyte maturity according to the scale defined by Rinchard and Kestemont (1996). In addition, percentage of oocytes at different stages of maturity and percentage distribution of oocytes according to size were studied. Oocyte size was determined with an accuracy of $1 \mu \mathrm{m}$, using an Ok.-15-KM micrometric eyepiece (PZO, Warsaw). The results were subjected to one-way analysis of variance (ANOVA), and the Mann-Whitney procedure was used to determine significant differences between the means for the control and experimental groups (8, 13, 24, and $49 \mathrm{mg}$ / $\mathrm{kg}$ ) as well as those in the experiment performed after 24 months of exposure $(8,13,24$, and $49 \mathrm{mg} / \mathrm{kg}$; 8-dep, 13 dep, 24-dep, and 49-dep). The differences were considered significant at $p \leq 0.05$. Spearman's correlation coefficients were calculated to observe relationship between oocyte diameter and $\mathrm{Pb}$ concentration in gonad's tissue.

\section{GSI analysis}

At 12 and 24 months of the experiment, the GSI was calculated during collection of gonads for histological analysis, using the formula [gonad weight/body weight without viscera] $\times 100$. To observe the relationships between GSI and $\mathrm{Pb}$ concentration in gonad's tissue, Spearman's correlation coefficients were calculated.

\section{LH analysis}

In order to determine the effect of exposure to different doses of lead, an experiment was performed after 12 and 24 months of exposure to investigate spontaneous LH levels as well as LH secretion following hormonal stimulation of the fish. Four days before the planned treatment, temperature in the aquaria was raised from 17 to $20^{\circ} \mathrm{C}$ in order to simulate the conditions of the natural environment prior to the spawning. On the day of the treatment, blood was collected from ten fish of each group, after which intraperitoneal injections of salmon gonadotropin releasing hormone analog (sGnRHa) $(10 \mu \mathrm{g}$ aGnRH/ $0.5 \mathrm{ml} / 1 \mathrm{~kg}$ b.wt; Bachem Feinchemikalien AG, Switzerland) and blocker of D-2 dopamine receptors - pimozide $(5 \mu \mathrm{g} /$ $0.5 \mathrm{ml} / 1 \mathrm{~kg}$ b.wt; Sigma-Aldrich, Germany) were performed to evaluate the influence of lead on LH secretion $(5 \mu \mathrm{g} / 0.5 \mathrm{ml} /$ $1 \mathrm{~kg}$ b.wt). Blood samples (about $100 \mu \mathrm{l}$ from each fish) were collected at 6, 12, and $24 \mathrm{~h}$ after the injection (Fig. 1) from the 
Table 1 Body weight of female fish after 6, 12, and 24 months of the experiment and total fish mortality

\begin{tabular}{|c|c|c|c|c|c|c|c|c|c|c|}
\hline Groups & 1 (control) & 2 & 2-dep & 3 & 3-dep & 4 & 4-dep & 5 & 5-dep & Total \\
\hline $\begin{array}{l}\text { Mean body weight }[\mathrm{g}] \text { of fish } \\
\text { at the beginning of exposure }\end{array}$ & $19.1 \pm 2 \mathrm{a}$ & \multicolumn{2}{|c|}{$19.7 \pm 2 \mathrm{a}$} & \multicolumn{2}{|c|}{$20.1 \pm 3 a$} & \multicolumn{2}{|c|}{$20.8 \pm 2 \mathrm{a}$} & \multicolumn{2}{|c|}{$19.9 \pm 2 \mathrm{a}$} & - \\
\hline $\begin{array}{l}\text { Mean body weight }[\mathrm{g}] \text { of fish } \\
\text { after } 6 \text { months of exposure }\end{array}$ & $25.3 \mathrm{a}$ & \multicolumn{2}{|l|}{$25.1 \mathrm{a}$} & \multicolumn{2}{|c|}{$23.1 \mathrm{a}$} & \multicolumn{2}{|l|}{$23 \mathrm{a}$} & \multicolumn{2}{|c|}{$24.3 \mathrm{a}$} & - \\
\hline $\begin{array}{l}\text { Mean body weight }[\mathrm{g}] \text { of fish } \\
\text { after } 12 \text { months of exposure }\end{array}$ & $40.4 \pm 6 \mathrm{a}$ & \multicolumn{2}{|c|}{$36.2 \pm 4 \mathrm{a}$} & \multicolumn{2}{|c|}{$30.9 \pm 4 a$} & \multicolumn{2}{|c|}{$27.1 \pm 4 a$} & \multicolumn{2}{|c|}{$30.6 \pm 6 a$} & - \\
\hline $\begin{array}{l}\text { Mean body weight [g] of fish } \\
\text { after } 24 \text { months of exposure }\end{array}$ & $51.2 \pm 8 \mathrm{ab}$ & $74 \pm 20 \mathrm{a}$ & $67 \pm 11 \mathrm{a}$ & $44 \pm 5 \mathrm{ab}$ & $65 \pm 8 \mathrm{a}$ & $48 \pm 12 \mathrm{ab}$ & $51 \pm 19 \mathrm{ab}$ & $53 \pm 13 \mathrm{a}$ & $34 \pm 7 b$ & - \\
\hline Total mortality [fish] & 2 & 1 & 0 & 1 & 1 & 0 & 2 & 1 & 1 & 9 \\
\hline
\end{tabular}

Different letters indicate statistically significant differences between groups

caudal vessels with a 1 -ml heparinized syringe $(0.4 \times 13 \mathrm{~mm}$ needle), centrifuged $(13,000 \times g, 3 \mathrm{~min})$ in Eppendorf tubes, and the blood plasma was kept at $-20{ }^{\circ} \mathrm{C}$ until ELISA determination of LH (Kah et al. 1989). Prior to all the manipulations, fish were anesthetized with Propiscin $(0.3 \mathrm{ml} / \mathrm{l}$; IRS, Zabieniec, Poland). The standards, LH hormone and antibodies, were donated by Dr. Bernard Breton (INRA, France). The results of the analysis were expressed as mean \pm standard error of the mean (SEM). The results were subjected to one-way ANOVA, and the Mann-Whitney procedure was used to determine significant differences between the means for the control and experimental groups $(8,13,24$, and $49 \mathrm{mg} / \mathrm{kg})$ as well as those in the experiment performed after 24 months of exposure $(8,13,24$, and $48 \mathrm{mg} / \mathrm{kg}$; 8-dep, 13-dep, 24-dep, and 49-dep). The differences were considered significant at $p \leq 0.05$.

To observe the relationships between $\mathrm{LH}$ secretion and $\mathrm{Pb}$ dose during exposure, Spearman's correlation coefficients were calculated.

$\mathrm{Pb}$ analysis

Prior to determination, ovary tissues ( $5 \mathrm{~g}$ weight) were subjected to preliminary mineralization in the presence of $10 \mathrm{ml}$, a $3: 1 v / v$ mixture of nitric acid $\left(65 \% \mathrm{HNO}_{3}\right)$ and perchloric acid $\left(70 \% \mathrm{HClO}_{4}\right)$ for about $20 \mathrm{~h}$. The samples were then heated with a Velp 20/26 digester by gradually increasing the temperature to $180{ }^{\circ} \mathrm{C}$ for $6-7 \mathrm{~h}$. The obtained clear liquid was diluted with deionized water to $10 \mathrm{ml}$ and then

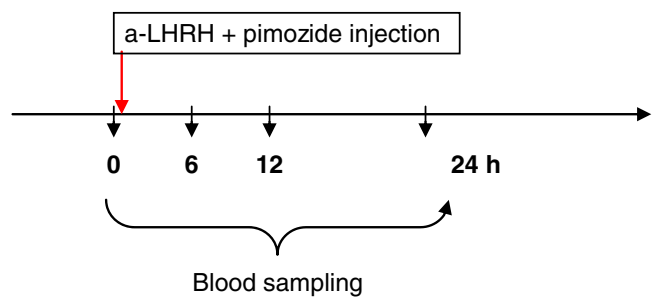

Fig. 1 Schematic representation of injections and blood collections in the experiment assayed for concentration of lead using a Unicam 929 atomic absorption spectrometer (Agemian et al. 1980). The concentrations were read from the standard curve generated, using the standards prepared based on atomic absorption standards made at the Office of Weights and Measures in Warsaw. Each sample was assayed in duplicate (the average values calculated from replicates were used in statistical analysis). Calibration was repeated every ten samples. The results were presented in milligrams of $\mathrm{Pb}$ per kilogram wet tissue weight (ww).

Minimum level of detection for lead was $0.001 \mathrm{mg} \mathrm{kg}^{-1}$.

The results were subjected to one-way analysis of variance, and significant differences were determined between the groups at each tissue collection as well as in each group between successive collections.

Spearman's correlation coefficients were calculated to examine the relationship between lead concentration in the ovary and dose of exposure.

\section{Results}

Histological analysis of the gonads

\section{After 6 months of exposure}

No differences between the groups were observed in external gonad structure except for gonadal weight, which was always significantly higher in the control group.

The ovaries harvested for analysis after 6 months of exposure to different doses of lead were in the third stage of gonadal maturity (according to the scale developed for cyprinids by Rinchard and Kestemont (1996)). Microscopic image shows oocytes of the protoplasmic growth period and oocytes at different stages of trophoplasmic growth. Compared to the ovary image, the number of oocytes undergoing trophoplasmic growth was observed to vary in different experimental groups, according to dose of exposure. In the 
control group, histological image showed an average of $14 \%$ oocytes undergoing trophoplasmic growth, but most (58 \%) oocytes were in protoplasmic growth stage. In the groups exposed to progressively higher doses of lead, the proportion of oocytes undergoing trophoplasmic growth was observed to increase according to the dose of lead. This proportion averaged $27 \%$ in the group exposed to $8 \mathrm{mg} \mathrm{Pb} \mathrm{kg}^{-1}, 39$ and $35 \%$ in the groups exposed to 13 and $49 \mathrm{mg} \mathrm{Pb} \mathrm{kg}^{-1}$, respectively, and was the highest (53\%) in the group exposed to $25 \mathrm{mg}$ $\mathrm{Pb} \mathrm{kg}^{-1}$ (Fig. 2).

Differences were also observed in the diameter of oocytes undergoing trophoplasmic growth. Mean diameter of oocytes in the control group and in the $8-\mathrm{mg} / \mathrm{kg}$ group were statistically significantly lower than in others (Table 2). In the control group, most oocytes (as much as over $59 \%$ ) had a diameter smaller than $0.5 \mathrm{~mm}, 31 \%$ of oocytes ranged from 0.51 to $0.75 \mathrm{~mm}$ in diameter, and only $9 \%$ had a diameter of 0.76 to $1 \mathrm{~mm}$. Larger oocytes were also found in the experimental groups, which is evidence that oocytes underwent more rapid trophoplasmic growth. In the $8-\mathrm{mg}-\mathrm{Pb}-\mathrm{kg}^{-1}$ group, oocytes ranging between 0.51 and $0.75 \mathrm{~mm}$ formed the greatest proportion, but larger ones (up to $1.5 \mathrm{~mm}$ in diameter) were also present. The largest oocyte dimensions (up to $2 \mathrm{~mm}$ in diameter) were observed in the $13-\mathrm{mg}-\mathrm{Pb}-\mathrm{kg}^{-1}$ group, and the greatest proportion $(33 \%)$ was made up by oocytes 0.76 $1.0 \mathrm{~mm}$ in size. In the $49-\mathrm{mg}-\mathrm{Pb}-\mathrm{kg}^{-1}$ group, there were no oocyte smaller than $0.76 \mathrm{~mm}$ (Fig. 3).

\section{After 12 months of exposure}

The samples of gonads collected after 12 months of exposure to different doses of lead showed the presence of oocytes in protoplasmic growth, oocytes in advanced stages of trophoplasmic growth, and mature oocytes with completed trophoplasmic growth, always with oogonia reserves. The ovaries were at maturity stage IV. The proportion of mature oocytes averaged $26 \%$ in the control group and was higher in the 8-, 13-, 24-, and 49-mg- $\mathrm{Pb}-\mathrm{kg}^{-1}$ experimental groups at $39,34,54$, and $30 \%$, respectively (Fig. 2).

The percentage of oocytes of different size ranges was similar in the experimental and control groups. The majority of mature oocytes ranged from 0.51 to $0.75 \mathrm{~mm}$ in size. In the control group, the proportion of such cells was $59 \%$. Only in the $8-\mathrm{mg}-\mathrm{Pb}-\mathrm{kg}^{-1}$ group has a greater proportion of oocytes

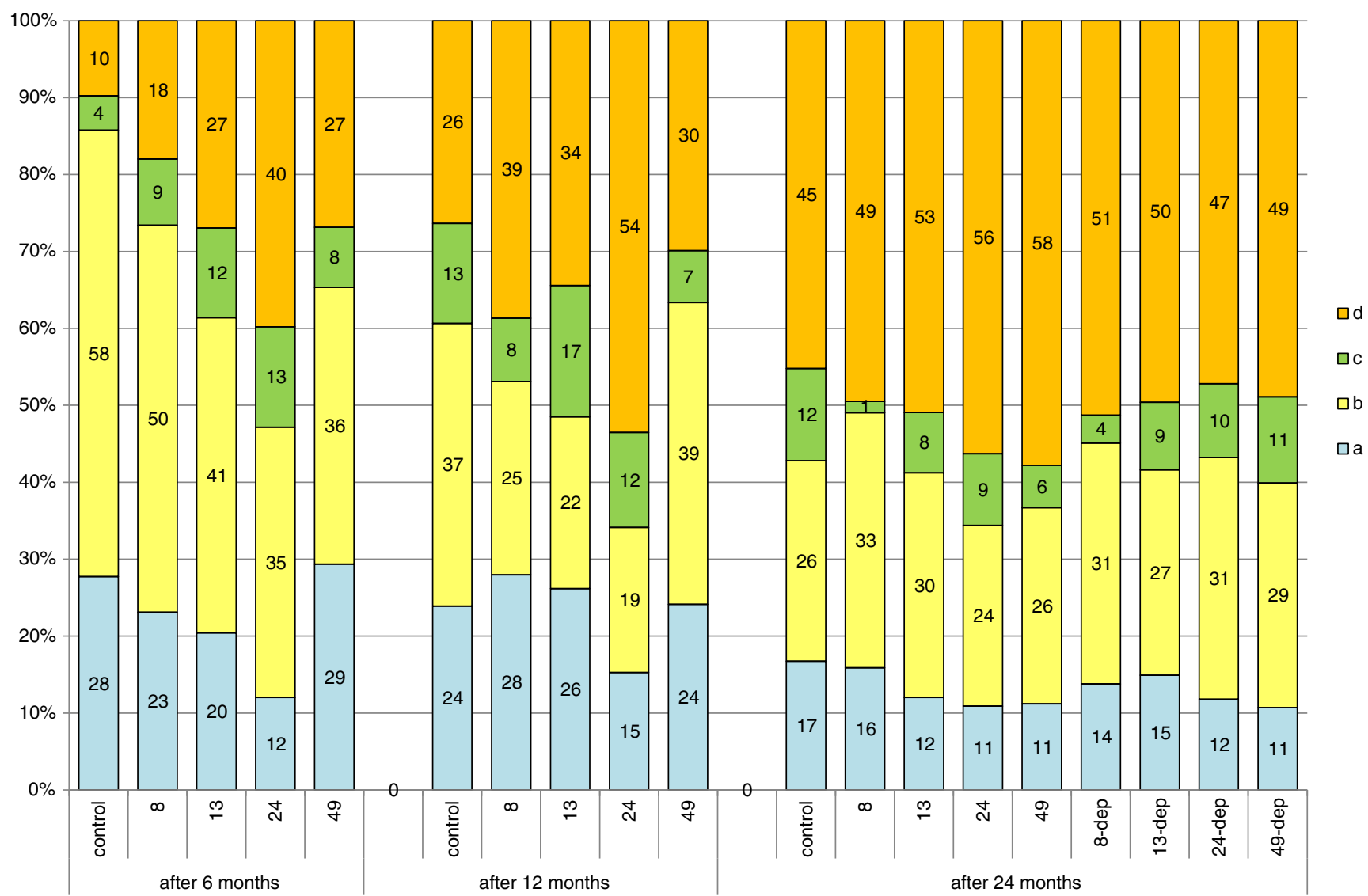

Fig. 2 Comparison of percentages of oogonia and oocytes at different developmental stages between the groups of females (controls, 8, 13, 24, and $48 \mathrm{mg} \mathrm{Pb} \mathrm{kg}^{-1}$ after 6 and 12 months of exposure and in females after 12 months of exposure and 12 months of depuration, groups 8-dep, 13- dep, 24-dep, and 48-dep) subjected to different lead exposure doses in successive years of the study: $A$ oogonia, $B$ oocytes in protoplasmic growth, $C$ oocytes entering trophoplasmic growth, $D$ oocytes in full trophoplasmic growth 
Table 2 Comparison of mean oocytes diameter after 6, 12, and 24 months and GSI values between experimental groups after 12 and 24 months of the study. Mann-Whitney test between each two groups and multiple comparisons Kruskal-Wallis test between all groups. Comparison of Spearman's correlation coefficients $(r)$ for the relationship between the oocytes diameter or GSI value and $\mathrm{Pb}$ concentration in gonads

\begin{tabular}{|c|c|c|c|c|c|c|c|c|c|c|c|}
\hline Months of exposure & Control & 8 & 13 & 24 & 49 & 8-dep & 13-dep & 24-dep & 49-dep & Statistic & $r$ \\
\hline & \multicolumn{11}{|c|}{ Mean oocytes diameter } \\
\hline 6 & $0.5 \mathrm{a}$ & $0.7 \mathrm{~b}$ & $1.2 \mathrm{c}$ & $1.1 \mathrm{c}$ & $1.1 \mathrm{c}$ & - & - & - & - & $p<0.001$ & $0.72 * * *$ \\
\hline 12 & $0.8 \mathrm{a}$ & $1.0 \mathrm{~b}$ & $0.8 \mathrm{a}$ & $0.8 \mathrm{a}$ & $0.8 \mathrm{a}$ & - & - & - & - & ns & -0.13 \\
\hline \multirow[t]{2}{*}{24} & $0.8 \mathrm{a}$ & $0.8 \mathrm{a}$ & $0.8 \mathrm{a}$ & $0.9 \mathrm{a}$ & $0.9 \mathrm{a}$ & $0.8 \mathrm{a}$ & $0.8 \mathrm{a}$ & $0.8 \mathrm{a}$ & $0.9 \mathrm{a}$ & ns & 0.14 \\
\hline & GSI & & & & & & & & & & \\
\hline 12 & $11 \mathrm{a}$ & $6 b$ & $7 b$ & $6 b$ & $8 \mathrm{~b}$ & - & - & - & - & $p<0.001$ & $-0.58 * * *$ \\
\hline 24 & 14 & 10 & 11 & 13 & 12 & 11 & 10 & 12 & 14 & ns & $-0.49^{*}$ \\
\hline
\end{tabular}

$* p<0.05 ; * * * p<0.001$

with a diameter over $0.75 \mathrm{~mm}$ observed (Fig. 3). In this group, diameter of oocyte were statistically significantly higher than in others (Table 2).

\section{After 24 months of exposure}

Gonads collected for analysis after 24 months of the experiment, both from fish under constant exposure to lead and those after a 12-month depuration period, were at maturity stage IV. They contained oocytes in protoplasmic and trophoplasmic growth, mature oocytes as well as oogonia reserves that formed $11-17 \%$ of oocytes in the field of vision. The percentage of mature oocytes was similar across groups, ranging from $45 \%$ in the control group to $58 \%$ in the $49-\mathrm{mg}$ $\mathrm{Pb}-\mathrm{kg}^{-1}$ group (Fig. 2). Slight, not significant statistically differences between the groups were noted when analyzing

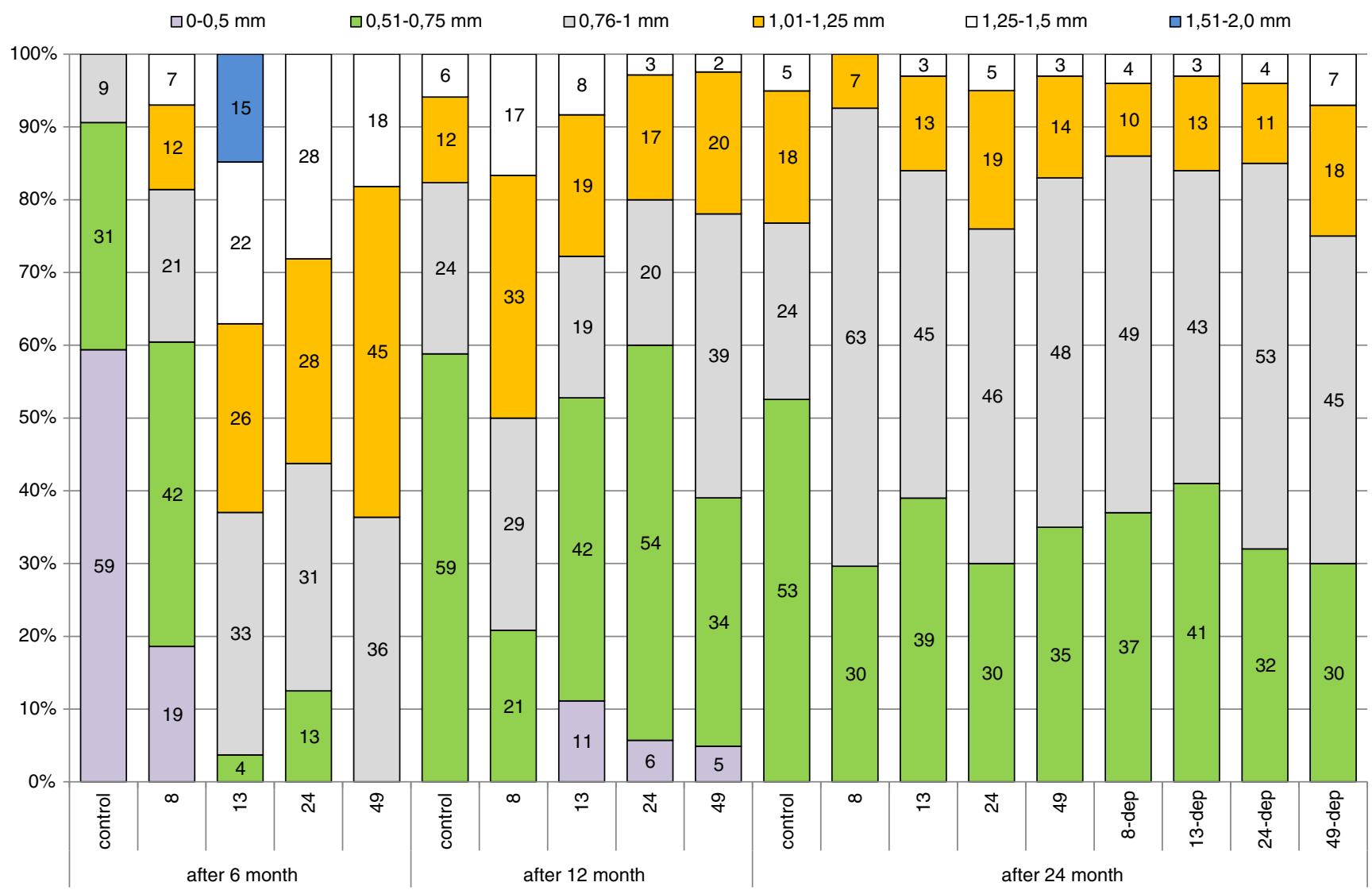

Fig. 3 Comparison of percentages of oocytes in different diameter ranges between female groups (controls, 8, 13, 24, and 49 $\mathrm{mg} \mathrm{Pb} \mathrm{kg}^{-1}$ ) after 6 and 12 months of exposure, and in females after 12 months of exposure and 12 months of depuration (groups 8-dep, 13-dep, 24-dep, and 49-dep) 
oocyte diameter. While in the control group, more than $50 \%$ of oocytes were between 0.51 and $0.75 \mathrm{~mm}$ in size; in the other groups, the largest proportion of oocytes ranged from 0.76 to $1 \mathrm{~mm}$ in size (Fig. 3).

\section{GSI}

The gonadosomatic index (gonad weight/body weight without viscera $\times 100$ ) was calculated after 12 and 24 months of the experiment. The average GSI values are shown in Table 2. GSI values of $\mathrm{Pb}$ treatment in groups of fish were statistically significantly lower than in control. No differences in GSI were observed between fish after 24 months of exposure to different doses of lead and females after a 12-month depuration period (Table 2). Significant negative correlation between GSI values and $\mathrm{Pb}$ concentration in gonad's tissue was noted after a 12month period $(r=-0.58 ; p<0.001)$ and after a 24 -month period $(r=-0.49 ; p<0.05)$ (Table 2$)$.

\section{LH concentration}

\section{After 12 months}

Statistical analysis of the results obtained for LH levels after 12 months of the experiment showed a significantly $(p<0.05)$ lower concentration of spontaneously released LH in the 8-, 13-, and 49-mg-Pb- $\mathrm{kg}^{-1}$ groups compared to the control group as well as a significant $(p<0.01)$ difference between the 8 - and 49-mg-Pb-kg ${ }^{-1}$ groups. As regards hormonally-stimulated LH secretion, $\mathrm{LH}$ concentration at $24 \mathrm{~h}$ postinjection was significantly $(p<0.01)$ higher in the 24- and 49-mg-Pb-kg ${ }^{-1}$ groups compared to the control group and the other groups (Fig. 4a) (Table 3).

Spearman's correlation coefficients were calculated to determine the relationships between LH secretion and $\mathrm{Pb}$ dose during exposure. Positive correlations of $r=0.35$ and $0.50(p<0.01)$ were noted 12 and $24 \mathrm{~h}$ after the stimulating injection (Table 3 ).

\section{After 24 months}

After 24 months of exposure, lower spontaneous LH secretion was observed in the $8-\mathrm{mg}-\mathrm{Pb}-\mathrm{kg}^{-1}$ group as well as higher $\mathrm{LH}$ secretion 12 and $24 \mathrm{~h}$ after the stimulating injection, but analysis of the results revealed no significant differences between the groups (Fig. 4b) (Table 3).

After the 12-month exposure period and the subsequent 12month depuration period, the level of both spontaneous and stimulated LH secretion was similar to that in the control group (Fig. 4b).
$\mathrm{Pb}$ concentration in ovaries

The results of analysis of $\mathrm{Pb}$ concentration in ovarian tissue, which was collected from female Prussian carp six times during the 24 months of exposure to different doses of lead, are given in Fig. 5. A significant increase in $\mathrm{Pb}$ concentration was already noticed after 3 months of exposure relative to baseline values in all the experimental groups (Fig. 5), as confirmed by statistically significant coefficients of correlation (Table 4). Pb concentration reached maximum levels after 6 and 12 months of exposure, decreased after 15 months of exposure, and again peaked from 18 months of exposure until the end of the study (Fig. 5). $\mathrm{Pb}$ accumulation during 12 months of exposure and the following 12-month depuration is presented in Fig. 6. It was observed that lead levels decreased after the spawning period 12 months after exposure (spawning triggered by an increase in water temperature), and no lead was accumulated in the next 12 months when fish received control feed. During the depuration phase, statistical analysis and Spearman's correlation coefficients were not significant (Table 4).

\section{Discussion}

While long-term exposure of fish to low doses of pollutants may produce no apparent effects, it may have a considerable impact on reproductive organs by reducing the size of the next generation and later by making the population slowly disappear (Kime 1995). Earlier studies by other authors reported pituitary damage, nuclear degeneration, or reduced hatching rates as a result of exposure to heavy metals (Fernicola et al. 1985; Popek et al. 2006).

This is one of the first long-term (24 month) studies to evaluate a range of environmentally relevant doses of dietary $\mathrm{Pb}$ to female Prussian carp. The study shows that over the first 12 months, there is a significant effect on oocytes maturation as well as a major effect on LH secretion, indicating that dietary $\mathrm{Pb}$ is an endocrine disruptor. However, a continuation in feeding to 24 months or a 12-month feed followed by a 12month depuration showed that the female Prussian carp return to control conditions.

The present study showed 8-30 \% higher proportions of oocytes in advanced stages of trophoplasmic growth in Prussian carp after 6 and 12 months of exposure to different doses of lead compared to the control (Fig. 2). Statistically significant differences were also observed in oocyte sizes, but $\mathrm{Pb}$ dose dependence was not noted. The lowest of used doses: $8 \mathrm{mg} / \mathrm{kg}$ was enough to significantly influence the egg's size (Table 2). While after 6 months of the experiment, the proportion of oocytes with a diameter greater than $0.75 \mathrm{~mm}$ was less than $10 \%$ in the control group; it was $40 \%$ in the $8-\mathrm{mg} / \mathrm{kg}$ group and exceeded $90 \%$ in the other groups exposed to even 
Fig. 4 Comparison of plasma LH concentrations in successive blood collections following the ovulation-stimulating injection after 12 (a) and 24 (b) months of female Prussian carp exposure to different doses of lead (groups 8, 13, 24, and $49 \mathrm{mg} \mathrm{Pb} \mathrm{kg}^{-1}$ ) and in females after 12 months of exposure and 12 months of depuration (groups 8-dep, 13-dep, 24-dep, and 49-dep) (b). Concentrations significantly different to control $(p<0.01)$ are marked with a star. No differences between groups after the 24-month exposure period as well as after the 12-month exposure and 12-month depuration periods. Error bars represent standard errors
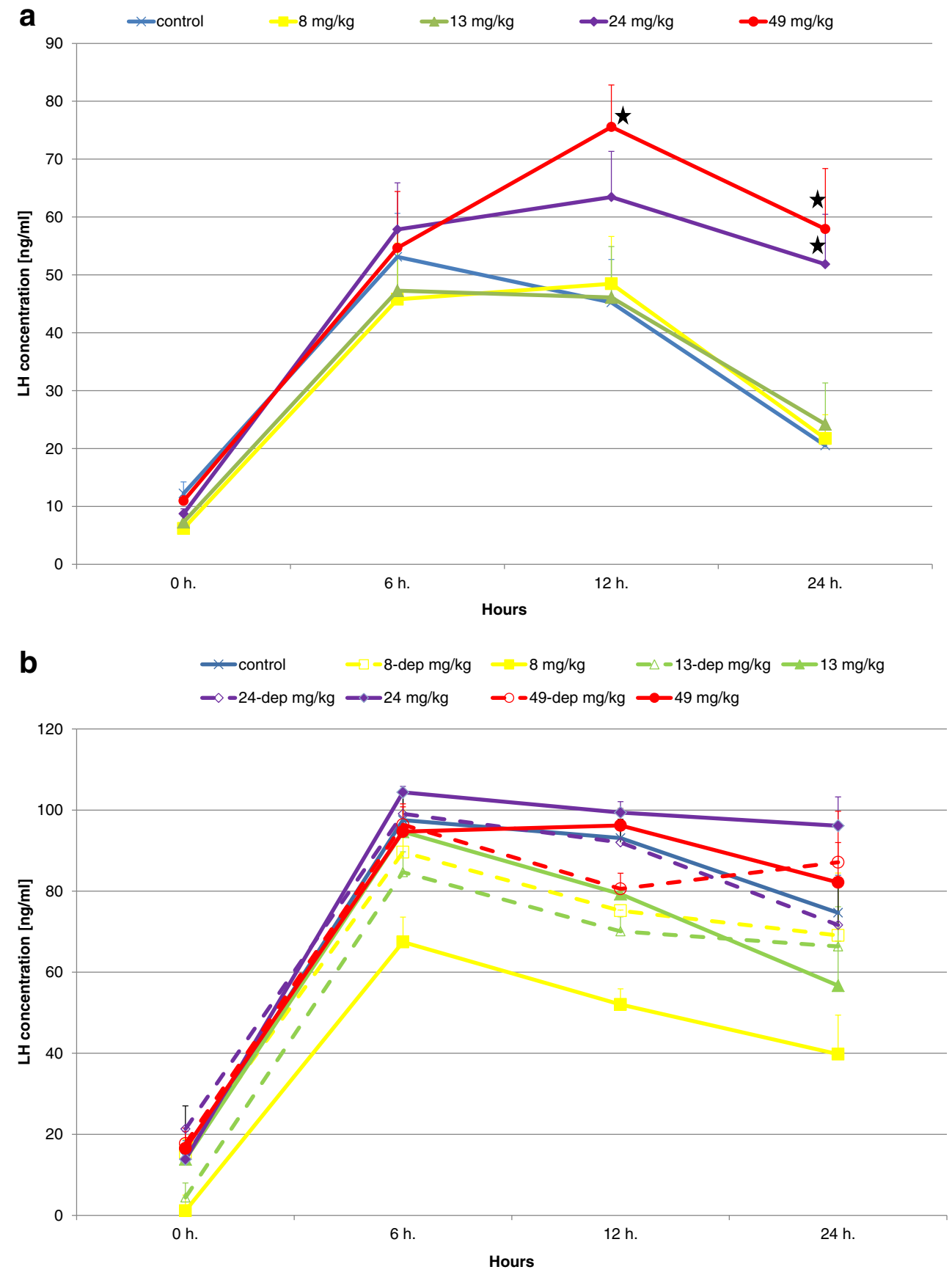

higher doses of lead. In our study, the largest oocytes (up to $2 \mathrm{~mm}$ ) were observed after 6 months of exposure to $13 \mathrm{mg}$ $\mathrm{Pb} \mathrm{kg}^{-1}$ (Fig. 3). Although, it was the only observation of such large oocyte diameter in the present study. A similar maximum diameter of ovulated oocytes of 0.35-2.03 mm $(1.06 \mathrm{~mm})$ was obtained before spawning from Prussian carp of $23.5-36 \mathrm{~cm}$ total length (Leonardos et al. 2008). One of the most important parameters used for determination of the reproductive potential is the variation of egg diameter in the ovary. Analyzing the relationship of oocyte diameter and $\mathrm{Pb}$ concentration in gonads, we can observe statistically significant correlation $r=0.72(p<0.0001)$, indicating that with increase of $\mathrm{Pb}$ bioaccumulation, egg's size increase (Table 2). This relation was noted only after the 6-month period of exposure.

After 12 months of exposure, larger oocytes were also observed in the groups exposed to lead, especially in the group exposed to the lowest dose of $8 \mathrm{mg} \mathrm{Pb} \mathrm{kg}^{-1}$, where the proportion of oocytes with a diameter greater than $0.75 \mathrm{~mm}$ was $80 \%$ compared to slightly over $40 \%$ in the control group 
Table 3 Statistical analysis results for LH concentration between different $\mathrm{Pb}$ exposure groups after 12 and 24 months of the experiment (MannWhitney test between each two groups and multiple comparisons Kruskal-Wallis test between all groups). Comparison of Spearman's correlation coefficients $(r)$ for the relationship of the level of spontaneous $\mathrm{LH}$ and after stimulating injection to dietary $\mathrm{Pb}$ level, after 12 and 24 months of the experiment

\begin{tabular}{|c|c|c|c|c|c|c|c|c|}
\hline \multirow[b]{2}{*}{ Hours } & \multicolumn{4}{|c|}{ After 12 months $\mathrm{Pb}$ exposure } & \multicolumn{4}{|c|}{ After 24 months $\mathrm{Pb}$ exposure and after 12 months exposure and 12 months depuration } \\
\hline & 0 & 6 & 12 & 24 & 0 & 6 & 12 & 24 \\
\hline Control & $\mathrm{ABa}$ & a & a & Aa & \multicolumn{4}{|c|}{ ns } \\
\hline 8 & $\mathrm{Ab}$ & $\mathrm{b}$ & a & Aa & \multirow{4}{*}{\multicolumn{4}{|c|}{$\begin{array}{l}\text { No differences between groups after the 24-month exposure period as well as after } \\
\text { the 12-month exposure and 12-month depuration period }\end{array}$}} \\
\hline 13 & $\mathrm{ABb}$ & $\mathrm{b}$ & $\mathrm{a}$ & $\mathrm{ABa}$ & & & & \\
\hline 24 & $\mathrm{AB}$ & $a b$ & $a b$ & $\mathrm{Bb}$ & & & & \\
\hline 49 & $\mathrm{Bc}$ & $a b$ & $\mathrm{~b}$ & $\mathrm{Bb}$ & & & & \\
\hline Kruskal-Wallis test & $p<0.01$ & ns & $p<0.05$ & $p<0.01$ & & & & \\
\hline $\mathrm{r}$ & 0.13 & 0.10 & $0.35 * *$ & $0.5^{* * *}$ & 0.11 & 0.03 & 0.14 & 0.10 \\
\hline r-dep & - & - & - & - & 0.20 & -0.21 & -0.18 & -0.02 \\
\hline
\end{tabular}

Uppercase letters signify $p<0.01$ and lowercase letters signify $p<0.05$

$* * p<0.01 ; * * * p<0.001$

(Fig. 3). Egg's size in this group was statistically significantly higher than in all other groups (Table 2). Different results during 12 days of exposure to lead were reported by Ruby et al. (2000), who observed larger egg diameters in control fish compared to female fish exposed to lead at a dose of $10 \mu \mathrm{g} / \mathrm{L}$. The differences in the observed effects could be speciesspecific, or due to exposure method, because Ruby exposed trout to lead for a short time in water, whereas in our study, the exposure of female Prussian carp to lead was chronic.

The GSI provides a general indicator of normal ovarian growth and reproductive development. As noted before, higher proportion of oocytes in advanced stages of trophoplasmic growth was observed in Prussian carp after 6 and 12 months of exposure to different doses of lead compared to the control (Fig. 2). Nevertheless, GSI values calculated after 12 months of exposure were significantly lower in the experimental fish (Table 2). This is supported by the findings of Ruby et al. (2000), who showed that when female rainbow trout were exposed during exogenous vitellogenesis, GSI in control fish was significantly lower than in fish after 12 days of exposure to $10 \mu \mathrm{g} \mathrm{Pb} / \mathrm{L}$. Opposite results obtained by Weber (1993) in reproductively mature fathead minnows maintained for 4 weeks in either 0.0 or $0.5 \mathrm{ppm} \mathrm{Pb}$. Lead suppressed spermatocyte production and retarded ovarian development, although no lead-induced gonadosomatic index changes for either sex were noted.

Negative, very significant correlation of GSI and $\mathrm{Pb}$ concentration in gonads $(r=-0,58 ; p<0.001)$ was observed after
Fig. 5 Comparison of $\mathrm{Pb}$ concentration in the ovarian tissue of female Prussian carp during 24 months of fish exposure to different dietary doses of this metal. Capital letters denote statistically significant differences $(p<0.05)$ between the groups in different exposure months, while small letters indicate significant differences in the groups between successive months of exposure (Mann-Whitney test). Error bars represent standard errors

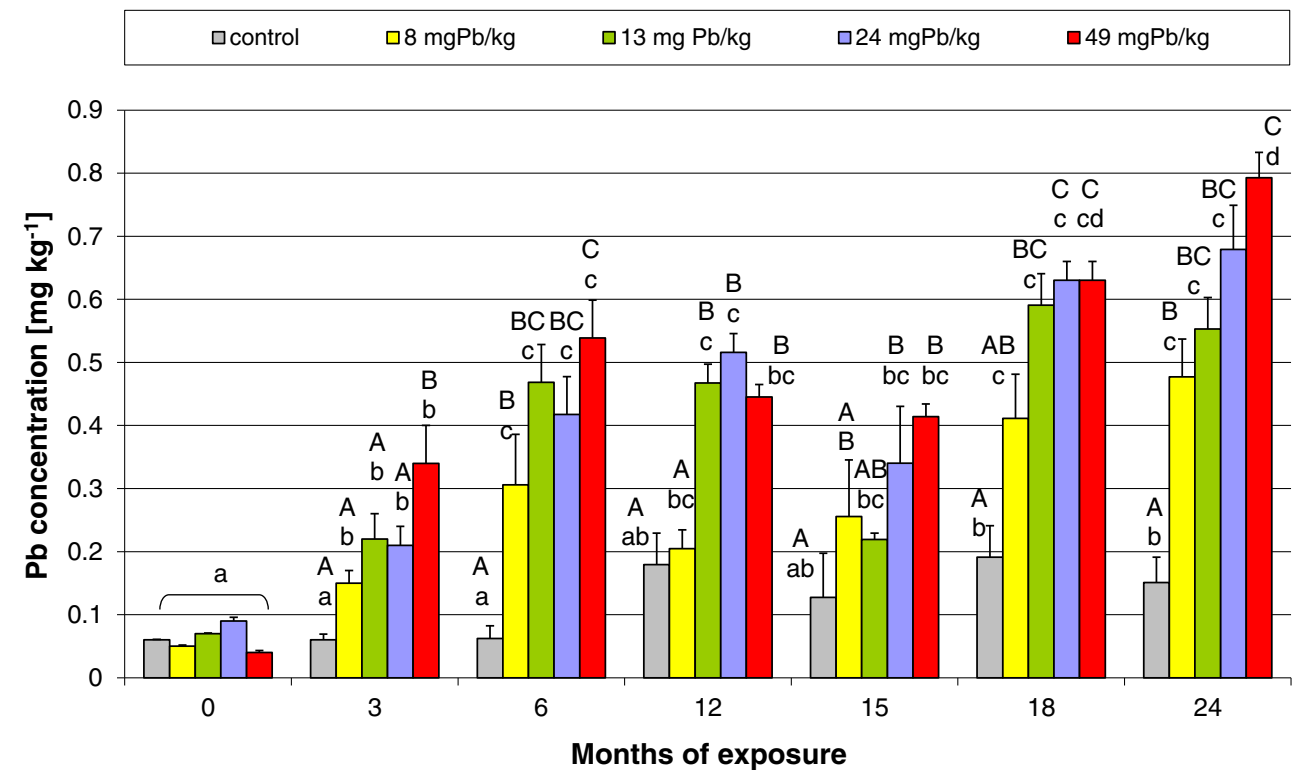


Table 4 Spearman's correlation coefficients $(r)$ for the relationship of $\mathrm{Pb}$ ovary concentration to lead dose during exposure in different groups

\begin{tabular}{|c|c|c|c|c|c|c|c|c|c|}
\hline & \multicolumn{6}{|c|}{ Exposure period } & \multicolumn{3}{|c|}{ Depuration period } \\
\hline & 3 & 6 & 12 & 15 & 18 & 24 & 3 & 6 & 12 \\
\hline$r$ & $0.74 * * *$ & $0.62 * * *$ & $0.60 * * *$ & 0.28 & $0.66 * * *$ & $0.61 * * *$ & 0.48 & 0.17 & 0.01 \\
\hline$p$ & ns & 0.0008 & 0.0001 & ns & 0.005 & 0.007 & ns & ns & $\mathrm{ns}$ \\
\hline
\end{tabular}

$p$ expresses the level of significant differences for gonadal lead concentration between female groups exposed to different metal doses in different periods of the experiment (multiple comparisons Kruskall-Wallis test)

$* * * p<0.001$

the 12-month period of exposure that clearly shows the impact of accumulated lead, although in this period, the relationship between $\mathrm{Pb}$ concentration and oocyte diameter was no longer observed (Table 2).

After 24 months of exposure, no clear differences were found in oocyte maturity, oocyte diameter, or GSI values between the control and experimental groups, regardless of lead exposure dose (Fig. 2, Table 2). Neither were any differences observed between the percentage of oocytes of different sizes in the groups of fish exposed to 12-month depuration following 12 months of exposure (Fig. 3). The negative relationship between GSI and $\mathrm{Pb}$ concentration was noted after the 24-month period of exposure but less significant statistically (Table 2). Fish tissues and body fluids contain naturally occurring proteins or glycoproteins of non-immunoglobulin (Ig) nature that react with a diverse array of environmental antigens and may confer an undefined degree of natural immunity to fish. They consist of microbial growth inhibitory compounds that include "acute phase" proteins such as transferrins, ceruloplasmin, and metallothionein. Their action is simply to chelate metal ions and deprive bacteria and other parasites of essential inorganic ion sources (Alexander and
Ingram 1992). Younger fish exhibit significantly lower antibody levels indicating that juvenile fish may not be able to mount an effective immune response as young adult fish (Hrubec et al. 2004). It may be that older fish, which completed maturation and have developed their defense mechanisms, cope better with the negative effects of environmental lead. Maybe the release of oocytes purge the fish of $\mathrm{Pb}$ and then as they mature for the second year, they do not accumulate, thus only 1 year of offspring may be effected.

One of the main causes of $\mathrm{Pb}$-related reproductive toxicity stems from the way this metal affects the endocrine system. In fact, there are numerous studies concerning the relationship between $\mathrm{Pb}$ exposure and physiological activity of hormones. The results of some studies suggest that the body's response to exposure to low doses of lead involves other mechanisms than the effects of higher doses (Iavicoli et al. 2006). Such biphasic responses have also been observed for estrogen and glucocorticoid receptor to arsenic (Bodwell et al. 2006; Davey et al. 2007). Junaid et al. (1997) investigated the ovarian toxicity of $\mathrm{Pb}$ in Swiss Albino female mice which were given $\mathrm{Pb}$ acetate for 60 days in three doses of either 2, 4, or $8 \mathrm{mg} \mathrm{kg}^{-1}$ day $^{-1}$. Data showed that $\mathrm{Pb}$ affects follicular development and
Fig. 6 Comparison of $\mathrm{Pb}$ concentration in the ovarian tissue of female Prussian carp during 12 months of dietary exposure to lead and 12 months of depuration. No significant differences between the groups after 3, 6, and 12 months of depuration, and a significant decrease $(p<0.01)$ (star) in concentration after 3month depuration compared to the 12th month of accumulation was found in the 13-, 24-, and 49-mg Pb kg ${ }^{-1}$-dep groups (Mann-Whitney test). Error bars represent standard errors

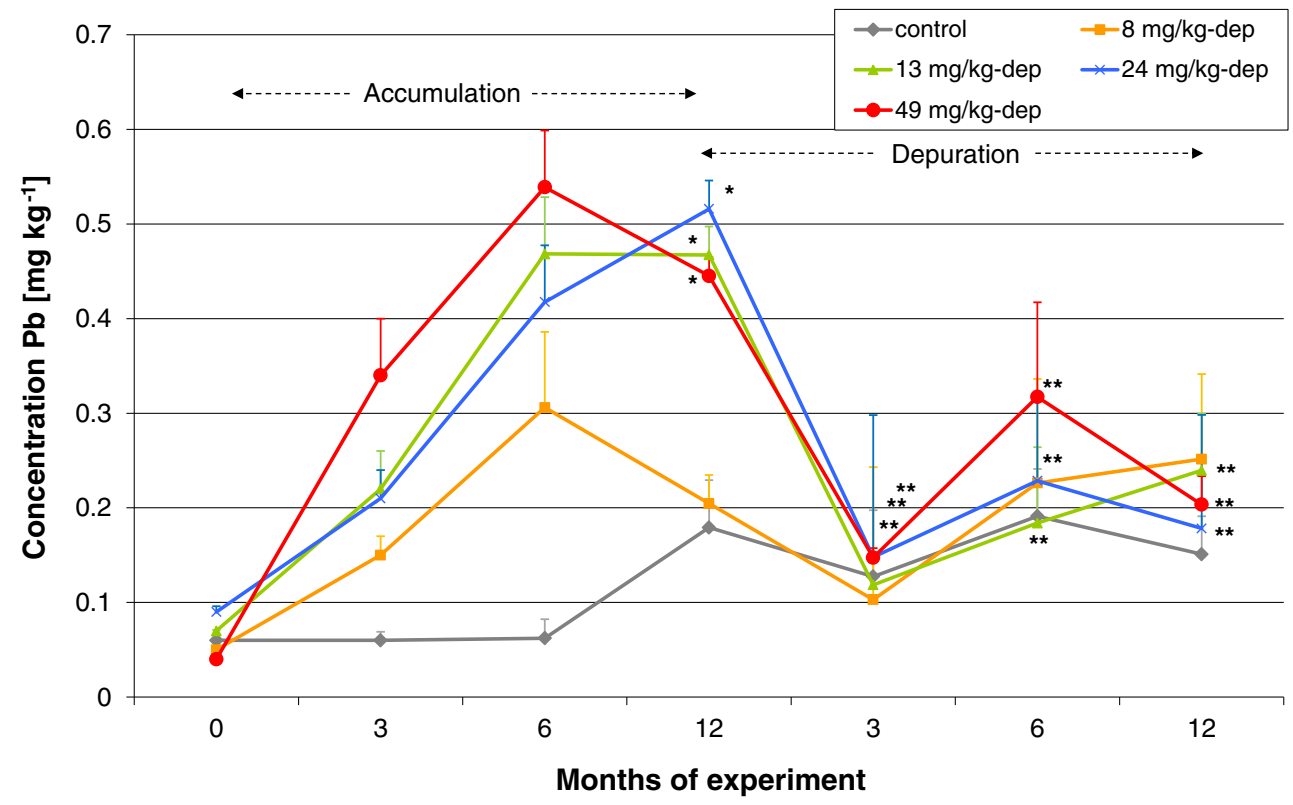


maturation at sufficiently high concentrations of 4 and $8 \mathrm{mg} \mathrm{kg}^{-1} \mathrm{day}^{-1}$. In particular, small and medium follicles were significantly affected even at the dose of $2 \mathrm{mg}$, while large follicles were affected mostly at the highest dose of $8 \mathrm{mg}$. In our study, we also observed varying body response to exposure to different doses of lead. After 12 months of exposure to the lowest of the experimental doses $(8 \mathrm{mg} / \mathrm{kg})$, spontaneous LH secretion was significantly lower than the control and other experimental groups. Meanwhile, in response to hormonal stimulation (LHRH-A + pimozide), a different reaction in the form of a prolonged period of elevated LH level was noted in the 24- and 49-mg/kg groups (Fig. 4a). This suggests that the body's response to lower exposure doses was governed by a different mechanism than in the case of higher exposure doses.

Changes in hormone secretion were also observed in a study in which lead acetate at a concentration of $12 \mathrm{mg} / \mathrm{ml}$ was administered with drinking water to pregnant and lactating female rats. Reduced fertility in the next generation and decreased secretion of some hormones, such as insulin-like growth factor (IGF-1), LH, and estradiol, were demonstrated (Dearth et al. 2002). Also young rats whose mothers were given lead $(0.05,0.15$, or $0.45 \% \mathrm{w} / \mathrm{v})$ during pregnancy and were themselves exposed to the same doses after weaning, showed a dose-dependent decrease in testosterone and $\mathrm{LH}$ secretion and an increase in the pituitary LH content (males) as well as suppressed plasma estradiol concentrations during maturation (females) (Ronis et al. 1998).

In mammals, there is significant evidence that the release of neurotransmitters including both norepinephrine and dopamine is altered following exposure to lead (Silbergeld 1983). The mechanisms of $\mathrm{Pb}$ neurotoxicity in fish have received far less consideration. However, from the limited number of studies available, it would seem that the effects are consistent with those observed in mammals (Mager 2011). Katti and Sathyanesan (1986) reported degenerative changes in both the nucleus preopticus (NPO) of the anterior neurohypophysis and nucleus lateralis tuberis (NLT) in the teleost Clarias batrachus following exposure to $5 \mathrm{ppm}$ of lead nitrate for 150 days. The NLT and probably part of NPO are involved in the regulation of gonadotrophic secretion by the pituitary in fishes (Peter 1970, 1982; Ball 1981). Lead has been found to affect various neurotransmitter systems in fish, including serotonergic (Spieler et al. 1995; Rademacher et al. 2003; Sloman et al. 2005), dopaminergic (Spieler et al. 1995; Rademacher et al. 2001), and noradrenergic (Spieler et al. 1995) pathways. The release of gonadotropins in teleosts is regulated in part by dopamine, which has been identified as the gonadotropin release-inhibiting factor in fish (Chang and Peter 1983; Chang et al. 1984), but it has not been shown to act in all teleosts. Popek et al. (2006) suggested that $\mathrm{Pb}$ reduces secretion of the stimulating hormone and increases the secretion of the inhibiting hormone involved in the regulation of the gonadotropic activity of the pituitary of carp females.

Lead can have an impact not only directly on LH secretion from the pituitary but also at lower levels of reproductive control because this metal negatively affects not only LH receptors in the ovary but also estradiol receptors in the body (Wiebe and Barr 1988; Wiebe et al. 1988). Ronis et al. (1996) suggested that $\mathrm{Pb}$ influences the hypothalamic-pituitary-gonadal axis at multiple action sites, while in in vitro experiments, Thomas (1988) showed no effect of $\mathrm{Pb}$ on steroidogenesis, although $\mathrm{Pb}$ reduced E2 levels in Atlantic croaker in vivo (Thomas 1990). Similarly contradictory results of $\mathrm{Pb}$ effect on steroid levels were also reported in adult male rats being unchanged (Nathan et al. 1992; Pinon-Lataillade et al. 1993) or decreased (Sokol and Berman 1991). These varied results indicate that $\mathrm{Pb}$ and other metals have multiple foci of action depending on the environment and nature of the insults. Lead elicited biphasic effects on estradiol-17 $\beta$, testosterone, and cortisol: stimulatory at lower concentrations and inhibitory at higher concentrations. The observation of such effects led the authors to make an unusual conclusion that in trace amounts, $\mathrm{Pb}$ may be beneficial (Chaube et al. 2010). The physiological significance of the stimulatory response of the low concentrations of $\mathrm{Pb}$ on the steroid levels is not clear. It may be that $\mathrm{Pb}$ like other essential metals $(\mathrm{Cu}, \mathrm{Zn}, \mathrm{Mn}$, etc.) at very low concentrations may be beneficial, if not essential for fish metabolism (Patra et al. 2006; Sprocati et al. 2006). But it seems very doubtful because of the lack of any evidences for the physiological role of $\mathrm{Pb}$.

In the experiment replicated after 24 months of female Prussian carp exposure to different doses of lead, similar relationships were observed in the form of lower level of spontaneous LH secretion and prolonged period of higher LH level following hormonal stimulation (Fig. 4b), but the differences were not significant (Table 3). Older, mature fish better coped with the exposure to lead, which did not produce such clear effects as those observed after 12 months of exposure to the same doses. It is also possible that the constant exposure to the action of the same toxicant caused the development of defense mechanisms in fish, which coped with its excess. Considering that some of the major effects of $\mathrm{Pb}$ toxicity are attributed to ionoregulatory and hematological alterations, several lines of evidence seem to indicate that fish are able to acclimate, at least to some extent, to $\mathrm{Pb}$ during chronic exposures (Mager 2011).

The lead was accumulated in the ovary from the beginning of the exposure because already after 3 months, the level of $\mathrm{Pb}$ was observed to increase significantly in all the groups, even in that with the lowest exposure dose of $8-\mathrm{mg}-\mathrm{Pb}-\mathrm{kg}^{-1}$ feed (Fig. 5). An important conclusion arises that food contamination even at a level of $\mathrm{Pb}$ as low as $8 \mathrm{mg} / \mathrm{kg}$ is not without an impact on the gonads, which intensively accumulate it. The level of lead accumulation in the ovary after 6 months of 
exposure did not change significantly compared to 12,18 , and 24 months, when the highest levels of lead were observed (Fig. 5), which suggests that after 6 months the analyzed tissue became saturated with lead; the concentration of which remained unchanged despite continued exposure. The steady state of $\mathrm{Pb}$ may reflect equilibrium between uptake and extrusion. The tissue reached a certain kind of homeostasis by not increasing $\mathrm{Pb}$ accumulation in the ovary while not inhibiting the ongoing oocyte maturation processes. The decrease in lead concentration in the ovary, observed at 15 months of exposure, could be due to the release of oocytes during the spawning period, which took place at 12 months of the experiment. After spawning, the ovaries replenished the lost lead and by 18 months ( 6 months after the spawning period), the gonads again had the maximum observed concentration of the metal, which persisted until the end of exposure (Fig. 5).

A clear depuration of gonads in females from the 8-dep, 13-dep, 24-dep, and 49-dep groups was already observed at 3 months after termination of exposure, when lead levels in the experimental groups equaled those in the control group (Fig. 6). The slight fluctuations in its concentration in the 49dep group, observed during the depuration phase, could result from the increased release of previously accumulated lead from other tissues into the blood, from where it could be secondarily accumulated in the depurated tissues (ŁuszczekTrojnar et al. 2013).

When analyzing the change in lead concentration in the ovaries from the control group, a significant increase in $\mathrm{Pb}$ level was noted at 18 and 24 months of the experiment. This was probably the consequence of long-term accumulation of the small amounts of lead $\left(0.1 \mathrm{mg} \mathrm{Pb} \mathrm{kg}{ }^{-1}\right)$ found in the control feed, which after 18 months of exposure caused $\mathrm{Pb}$ level to increase from 0.06 to $0.19 \mu \mathrm{g} \mathrm{g}^{-1}$ of tissue (Fig. 5). This effect confirms that the ovarian tissue is sensitive to lead accumulation even with very low levels of environmental contamination.

\section{Conclusions}

Chronic exposure to lead is not without an influence on the reproductive system of female Prussian carp. The negative effect is manifested by a decrease in GSI value after 12 months despite the fact that after 6 months, and even more noticeably after 12 months, a higher proportion of oocytes at more advanced stages of maturity is observed.

After 12 months of exposure, the effect on LH secretion varied according to the dose. In the group exposed to the lowest dose $(8 \mathrm{mg} / \mathrm{kg})$, LH decreased spontaneously, and in the groups exposed to the highest two doses (24 and $49 \mathrm{mg}$ / $\mathrm{kg}$ ), a significantly higher, LHRH-A-stimulated LH secretion was observed. This supports the conclusions of other authors that the body's response to lower exposure doses may be governed by a different mechanism compared to higher doses.

After 24 months of lead exposure, the effects on oocyte maturation and size and on the GSI values were not so pronounced. Analysis of the effect of lead exposure on LH secretion showed that the relationships were similar to those observed after 12 months but nonsignificant.

After 12 months of exposure and 12 months of depuration, the levels of spontaneous and stimulated LH secretion observed in all the groups were similar to the control, which is evident that the depuration eliminates the previously observed effects of exposure to lead.

Lead is easily accumulated in the ovary reaching, depending on exposure, a fivefold higher level $(0.8 \mathrm{mg} / \mathrm{kg}$ of tissue $)$ compared to the control $(0.15 \mathrm{mg} / \mathrm{kg}$ of tissue $)$, but after discontinuation of exposure, this organ is quickly depurated.

The present results indicate that environmental $\mathrm{Pb}$ can be a potent endocrine disruptor, affecting ovarian steroidogenesis, gametogenesis, and ovulation, which may lead to adverse impact on fish reproduction and population density and that female Prussian carp become resistant to the negative effects of lead with advancing age, and their organisms cope by reaching a state of homeostasis.

Acknowledgments The authors are grateful to Prof. dr hab. Tomasz Mikołajczyk for his assistance and help during the experiments. The research project was supported by Ministry of Science and Higher Education in Poland grant no. N 311012 31/3829 and DS-KIiR-3202/12. The research project was approved by the Local Ethics Commission (permission no. 87/P/2005).

Open Access This article is distributed under the terms of the Creative Commons Attribution License which permits any use, distribution, and reproduction in any medium, provided the original author(s) and the source are credited.

\section{References}

Agemian H, Sturtevant DP, Austen KD (1980) Simultaneous acid extraction of six trace metals from fish tissue by hot-block digestion and determination by atomic-absorption spectrometry. Analyst 105(1247):125-130

Alexander JB, Ingram GA (1992) Noncellular nonspecific defence mechanisms of fish. Annu Rev Fish Dis 2:249-279

Al-Saleh J, Coskun S, Mashhour A, Shinwari N, El-Doush I, Billedo G, Jaroudi K, Al-Shahrani A, Al-Kabra M, Eldin Mohamed G (2008) Exposure to heavy metals (lead, cadmium and mercury) and its effect on the outcome pf in-vitro fertilization treatment. Int J Hyg Environ Health 211(5-6):560-579

Ball JN (1981) Hypothalamic control of the pars distalis in fishes, amphibians and reptiles. Gen Comp Endocrinol 44:135-170

Birge WJ, Black JA, Westerman AG, Hudson JE (1979) The effects of mercury on reproduction of fish and amphibians. In: Nriagu JO (ed) The biogeochemistry of mercury in the environment (topics in environmental health Series), vol 3. Elsevier, Amsterdam, pp 629655 
Bodwell JE, Gosse JA, Nomikos A, Hamilton JW (2006) Arsenic disruption of steroid receptor gene activation: complex dose-response effects are shared by several steroid receptors. Chem Res Toxicol 19(12):1619-1629

Boroń A, Szlachciak J, Juchno D, Grabowska A, Jagusztyn B, Porycka K (2011) Karyotype, morphology, and reproduction ability of the Prussian carp, Carassius gibelio (Actinopterygii: Cypriniformes: Cyprinidae), from unisexual and bisexual populations in Poland. Acta Ichthyol Piscat 41(1):19-28

Brown V, Shurben D, Miller W, Crane M (1994) Cadmium toxicity to rainbow trout Oncorhynchus mykiss Walbaum and brown trout Salmo trutta L. over extended exposure periods. Ecotoxicol Environ Saf 29:38-46

Chang JP, Peter RE (1983) Effects of dopamine on gonadotropin release in female goldfish, Carassius auratus. Neuroendocrinology 36:351-357

Chang J, Peter RE, Nahorniak CS, Sokolowska M (1984) Effects of catecholaminergic agonists and antagonists on serum gonadotropin concentrations and ovulation in goldfish: evidence for specificity of dopamine inhibition of gonadotropin secretion. Gen Comp Endcrinol 55:351-360

Chaube R, Mishra S, Rahil Singh K (2010) In vitro effects of lead nitrate on steroid profiles in the postvitellogenic ovary of the catfish Heteropneustes fossilis. Toxicol in Vitro 24:1899-1904

Crump KL, Trudeau VL (2009) Mercury-induced reproductive impairment in fish. Environ Toxicol Chem 28:895-907

Davey JC, Bodwell JE, Gosse JA, Hamilton JW (2007) Arsenic as an endocrine disruptor: effects of arsenic on estrogen receptor-mediated gene expression in vivo and in cell culture. Toxicol Sci 98(1):75-86

Dearth RK, Hiney JK, Srivastava V, Burdick SB, Bratton GR, Dees WL (2002) Effects of lead (PB) exposure during gestation and lactation on female pubertal development in the rat. Reprod Toxicol 16:343-352

Ebrahimi M, Taherianfard M (2011) The effects of heavy metals exposure on reproductive systems of cyprinid fish from Kor River. Iran J Fish Sci 10(1):13-24

Fan Z, Liu G (1990) The ploidy and reproductive mechanism of crucian carp, C. auratus gibelio. J Fish Biol 36(3):415-419

Farag AM, Woodward DF, Brumbaugh W, Goldstein JN, Mac Connell E, Hogstrand C, Barrows FT (1999) Dietary effects of metalscontaminated invertebrates from the Coeur d'Alene River, Idaho on cutthroat trout. Trans Am Fish Soc 128:578-592

Fernicola C, Govoni S, Coniglio L, Trabucchi M (1985) Toxicologic hazards at the endocrine level of heavy metals. G Ital Med Lav Ergon 7(5-6): 175-180

Goyer RA (1986) Toxic effects of metals. In: Klaassen CD, Amdur MO, Doull J (eds) Casarett and Doull's toxicology, 3rd edn. Macmillan, New York, pp 582-635

Has-Schön E, Bogut I, Rajković V, Bogut S, Cacic M, Horvatić J (2008) Heavy metal distribution in tissues of six species included in human diet, inhabiting freshwaters of the Nature Park "Hutovo Blato" (Bosnia and Herzegovina). Arch Environ Contam Toxicol 54:75-83

Hodson PV, Blunt BR, Spry DJ (1978) Chronic toxicity of water-borne and dietary lead to rainbow trout (Salmo gairdneri) in Lake Ontario water. Water Res 12:869-878

Hrubec TC, Ward D, Smith SA, Robertson JL (2004) Age related changes in humoral immune response of hybrid strioped bass (Morone chrysops $\mathrm{x}$ Morone saxatilis). Vet Immunol Immunopathol 101(12):103-108

Humason GL (1967) Animal tissue techniques, 2dth edn. WH Freeman, San Francisco

Iavicoli I, Carelli G, Stanek EJ, Castellino N, Calabrese EJ (2004) Effects of low doses of dietary lead on puberty onset in female mice. Reprod Toxicol 19:35-41

Iavicoli I, Carelli G, Stanek EJ, Castellino N, Calabrese EJ (2006) Low doses of dietary lead are associated with a profound reduction in the time to the onset of puberty in female mice. Reprod Toxicol 22:586590
Junaid M, Chowdhuri DK, Narayan R, Shanker R, Saxena DK (1997) Lead-induced changes in ovarian follicular development and maturation in mice. J Toxicol Environ Health A 50:31-40

Kah O, Pontet A, Ridriguez JN, Calas A, Breton B (1989) Development of enzyme-linked immunosorbent assay for goldfish gonadotropin. Biol Reprod 40:68-73

Katti SR, Sathyanesan AG (1986) Changes in the hypothalamoneurohypophysial complex of lead treated teleostean fish Clarias batrachus (L.). Z mikrosk-anat Forsch, Leipzig 100:347352

Khan IA (2000) Lead and Aroclor 1254 disrupt reproductive neuroendocrine function in Atlantic croaker. Mar Environ Res 50:119-123

Kidd KA, Blanchfield PJ, Mills KH, Palace VP, Evans RE, Lazorchak JM, Flick RW (2007) Collapse of a fish population after exposure to a synthetic estrogen. PNAS 104(21):8897-8901

Kime DE (1995) The effects of pollution on reproduction in fish. Rev Fish Biol Fish 5(1):52-96

Kirubagaran R, Joy KP (1992) Toxic effects of mercury on testicular activity in the fresh-water teleost, Clarias batrachus (L.). J Fish Biol 41:305-315

Leonardos ID, Tsikliras AC, Eleftheriou V, Cladas Y, Kagalou I, Chortatou R, Papigioti O (2008) Life history characteristics of an invasive cyprinid fish (Carassius gibelio) in Chimaditis Lake (northern Greece). J Appl Ichthyol 24:213-217

Lucchi L, Memo M, Airaghi ML, Spano PF, Trabucchi M (1981) Chronic lead treatment induces in rate a specific and differential effect on dopamine receptors in different brain areas. Brain Res 213:397-404

Łuszczek-Trojnar E, Drag-Kozak E, Popek W (2013) Lead accumulation and elimination in tissues of Prussian carp, Carassius gibelio (Bloch, 1782), after long-term dietary exposure, and depuration periods. Environ Sci Pollut Res 20(5):3122-3132

Mager EM (2011) Lead. In: Wood CM, Farrell AP, Brauner CJ (eds) Homeostasis and toxicology of non-essential metals. Fish physiology, vol 31B. Academic, New York, pp 185-236

Mahalakshmi M, Balakrishnan S, Indira K, Muthukumarasamy S (2012) Characteristic levels of heavy metals In cannes tuna fish. J Toxicology Environ Health Sci 4(2):43-45, Short Communication

Nathan E, Hung HRS, Pogach Giglio W, Bogden JD, Seebode J (1992) Lead acetate does not impair secretion of sertoli cell marker proteins in adult Sprague-Dawley rat. Arch Environ Health 47:370-375

Olsson PE, Kling P, Petterson C, Silversand C (1995) Interaction of cadmium and oestradiol- 17 beta on metallothionein and vitellogenin synthesis in rainbow trout (Oncorhynchus mykiss). Biochem J 307: 197-203

Patra RC, Swarup D, Sharma MC, Naresh R (2006) Trace mineral profile in blood and hair from cattle environmentally exposed to lead and cadmium around different industrial units. J Vet Med A Physiol Pathol Clin Med 53:511-517

Peter RE (1970) Hypothalamic control of the thyroid activity and gonadal activity in the goldfish, Carassius auratus. Gen Comp Endocrinol $14: 334-356$

Peter RE (1982) Neuroendocrine control of reproduction in teleosts. Can J Fish Aquat Sci 39:48-55

Pinon-Lataillade G, Thorevx Monalay A, Coffigny H, Masse R, Monchaux G, Soufi JC (1993) Effect of ingestion and inhalation of lead on the reproductive system and fertility of adult male rats and their progeny. Hum Exp Toxicol 13:165-172

Popek W, Dietrich G, Glogowski J, Demska-Zakes K, Drag-Kozak E, Sionkowski J, Luszczek-Trojnar E et al (2006) Influence of heavy metals and 4-nonylphenol on reproductive function in fish. Reprod Biol 6(1):175-188

Rademacher DJ, Steinpreis RE, Weber DN (2001) Short-term exposure to dietary $\mathrm{Pb}$ and/or DMSA affects dopamine and dopamine metabolite levels in the medulla, optic tectum, and cerebellum of rainbow trout (Oncorhynchus mykiss). Pharmacol Biochem Behav 70:199 207 
Rademacher DJ, Steinpreis RE, Weber DN (2003) Effects of dietary lead and/or dimercaptosuccinic acid exposure on regional serotonin and serotonin metabolite content in rainbow trout (Oncorhynchus mykiss). Neurosci Lett 339:156-160

Ram RN, Joy KP (1988) Mercurial induced changes in the hypothalamoneurohypophysical complex in relation to reproduction in the teleostean fish, Channa punctatus (Bloch). Bull Environ Contam Toxicol 41:329-336

Ram RN, Sathyanesan AG (1983) Effect of mercuric chloride on the reproductive cycle of the teleostean fish Channa punctatus. Bull Environ Contam Toxicol 30:24-27

Rinchard J, Kestemont P (1996) Comparative study of reproductive biology in single-and multiple-spawner cyprinid fish. I. Morphological and histological features. J Fish Biol 49:883-894

Ronis MJ, Badger TM, Shema SJ, Roberson PK, Shaikh F (1996) Reproductive toxicity and growth effects in rats expose to lead at different periods during development. Toxicol Appl Pharmacol 136: 361-371

Ronis MJ, Gandy J, Badger T (1998) Endocrine mechanisms underlying reproductive toxicity in the developing rat chronically exposed to dietary lead. J Toxicol Environ Health A 54:77-99

Ruby SM, Jaroslawski P, Hull R (1993) Lead and cyanide toxicity in sexually maturing rainbow trout, Oncorhynchus mykiss during spermatogenesis. Aquat Toxicol 26:225-238

Ruby SM, Hull R, Anderson P (2000) Sublethal lead affects pituitary function of rainbow trout during exogenous vitellogenesis. Arch Environ Contam Toxicol 38:46-51

Silbergeld EK (1983) Experimental studies of lead neurotoxicity: implications for mechanisms, dose-response and reversibility. In: Rutler M, Jones RE (eds) Lead versus health. Wiley, London, pp 191-222

Sloman KA, Lepage O, Rogers JT, Wood CM, Winberg S (2005) Sociallymediated differences in brain monoamines in rainbow trout: effects of trace metal contaminants. Aquat Toxicol 71:237-247

Snarski VM, Olson GF (1982) Chronic toxicity and bioaccumulation of mercuric chloride in the fathead minnow (Pimephales promelas). Aquat Toxicol 2:143-156

Sokol RZ, Berman N (1991) The effect of age of exposure on leadinduced testicular toxicity. Toxicology 69:269-278

Spieler RE, Russo AC, Weber DN (1995) Waterborne lead affects circadian variations of brain neurotransmitters in fathead minnows. Bull Environ Contam Toxicol 55:412-418

Sprocati AR, Alisi C, Segre L, Tasso F, Galletti M, Cremisini C (2006) Investigating heavy metal resistance, bioaccumulation and metabolic profile a metallophile microbial consortium native to an abandoned mine. Sci Total Environ 366:649-658

Sumpter JP, Jobling S (2013) The occurrence, causes and consequences of estrogens in the aquatic environment. Environ Toxicol Chem 32(2):249-251

Syasina IG, Khlopova AV, Chukhlebova LM (2012) Assessment of the state of the gibel carp Carassius auratus gibelio in the Amur River Basin: heavy-metal and arsenic concentrations and histopathology of internal organs. Arch Environ Contam Toxicol 62(3):465-478

Szczerbik P, Mikołajczyk T, Sokołowska-Mikołajczyk M, Socha M, Chyb J, Epler P (2006) Influence of long-term exposure to diet ary cadmium on growth, maturation and reproduction of goldfish (subspecies: Prussian carp Carassius auratus gibelio B.). Aquat Toxicol 77(2):126-135

Taupeau C, Poupon J, Treton D et al (2003) Lead $(\mathrm{Pb} 2+)$ reduces mRNA and protein levels of cytochrome P-450 aromatase and estrogen receptorbeta in human ovarian granulosa cells. Biol Reprod 68: 1982-1988

Thomas P (1988) Reproductive endocrine function in female Atlantic croaker exposed to pollutants. Mar Environ Res 24:179-183

Thomas P (1990) Teleost model for studying the effect of hemical on female reproductive endocrine function. J Exp Zool Suppl 4:126-128

Vyskocil A, Fiala Z, Ettlerová E, Tenjnorová I (1990) Influence of chronic lead exposure on hormone levels in developing rats. J Appl Toxicol 10(4):301-302

Weber DN (1993) Exposure to sublethal levels of waterborne lead alters reproductive behavior patterns in fathead minnows (Pimephales promelas). Neurotoxicol 14(2-3):347-358

Wiebe JP, Barr KJ (1988) Effect of prenatal and neonatal exposure to lead on the affinity and number of estradiol receptors in the uterus. $\mathrm{J}$ Toxicol Environ Health 24:451-460

Wiebe JP, Barr KJ, Buckingham KD (1988) Effect of prenatal and neonatal exposure to lead on gonadotropin receptors and steroidogenesis in rat ovaries. J Toxicol Environ Health 24:461-476

Woodward DF, Brumbaugh WG, DeLonay AJ, Little EE, Smith CE (1994) Effects on rainbow trout fry of metals-contaminated diet of benthic invertebrates in the Clark Fork River, Montana. Trans Am Fish Soc 123:51-62

Yi YJ, Zhang SH (2012) Heavy metal (Cd, Cr, Cu, Hg, Pb, Zn) concentrations in seven fish species in relation to fish size and location along the Yangtze River. Environ Sci Pollut Res 19(9):3989-3996

Zawistowski S (1986) Histological techniques, histology and the foundations of histopathology. PZWL, Warszawa, 548 p. [In Polish] 